\title{
FREQUENCY OF SYMPTOMATIC SPONTANEOUS BACTERIAL PERITONITIS AND ASSOCIATED CLINICAL PARAMETERS IN PATIENTS WITH LIVER CIRRHOSIS
}

\author{
Syed Fayyaz Mehmood Gilani, Fayyaz Hassan*, Fuad Ahmad Siddiqi*, Syed Anees Ahmed Gardezi \\ Combined Military Hospital Kharian/National University of Medical Sciences (NUMS) Pakistan, ${ }^{*}$ Combined Military Hospital/National University of Medical \\ Sciences (NUMS) Rawalpindi Pakistan
}

\begin{abstract}
Objective: To study association between spontaneous bacterial peritonitis and clinical symptoms in liver cirrhosis.

Study Design: cross-sectional study.

Place and Duration of Study: Combined Military Hospital Kharian, from Jul 2019 to Apr 2020.

Methodology: A total of 122 patients of liver cirrhosis (irrespective of aetiology), presented with various clinical symptoms such as fever, pain abdomen and hepatic encephalopathy were randomly selected. Patients between 18-80 years of age, were included in the study. Asymptomatic patients, with ascites other than liver cirrhosis were excluded. Spontaneous Bacterial Peritonitis was defined as positive ascitic fluid culture and/or ascitic polymorphonuclear leukocyte $\geq 250 \mathrm{cells} / \mathrm{mm}^{3} \mathrm{in}$ ascitic fluid.

Results: Of the 122 randomly selected patients, the mean age was $56.5 \pm 20.2$ years. Forty-Five $(46.8 \%)$ were male and $67(54.2 \%)$ patients were female. Chronic Hepatitis C was the commonest cause of liver cirrhosis $(92 \%)$. The frequency of spontaneous bacterial peritonitis was $37.7 \%$. Majority, (83\%) of the culture positive ascitic isolate was Gram negative bacilli and E.coli $(72 \%)$ being the commonest organism isolated. Severe ascites, high International Normalized Ratio (INR), hepatic encephalopathy, fever, low ascetic fluid protein count, high serum bilirubin and creatinine were considered to be independent predictor of Spontaneous Bacterial Peritonitis.

Conclusion: Clinical symptoms of fever, hepatic encephalopathy, severe ascites, International Normalized ratio high and deranged renal profile was highly suggestive of Spontaneous Bacterial Peritonitis in cirrhotic patients.
\end{abstract}

Keywords: Ascites, Bilirubin, Cirrhosis, Creatinine, Encephalopathy.

How to Cite This Article: Gilani SFM, Hassan F, Siddiqi FA, Gardezi SAA. Frequency of Symptomatic Spontaneous Bacterial Peritonitis and Associated Clinical Parameters in Patients with Liver Cirrhosis. Pak Armed Forces Med J 2021; 71(5): 1598-1602. doi: https://doi.org/10.51253/pafmj.v71i5.4758

This is an Open Access article distributed under the terms of the Creative Commons Attribution License (https://creativecommons.org/licenses/by-nc/4.0/), which permits unrestricted use, distribution, and reproduction in any medium, provided the original work is properly cited.

\section{INTRODUCTION}

Incidence of chronic liver disease is on the rise worldwide over the last few decades. Every year 14-26 new cases per 100,000 population are being included in the pool. ${ }^{1}$ According to the latest survey, chronic viral hepatitis is one of the four major causes of chronic liver disease leading to cirrhosis. ${ }^{2}$ Cirrhosis, in majority of cases, leads to ascites which in turn, may lead to Spontaneous Bacterial Peritonitis (SBP) which is a potentially life threatening complication particularly in hospitalized patients. ${ }^{3}$

SBP is a fatal condition occurring in patients with chronic liver disease with ascites. A large numbers of studies found that $12-34 \%$ of indoor patients and. ${ }^{2-3}$ Percentage of patients reporting in outdoor clinics with chronic liver disease and ascites had SBP, with mortality ranging from $20-40 \% .^{4-5}$ SBP may be the cardinal risk factor for life threating complications leading to

Correspondence: Dr Syed Fayyaz Mehmood Gilani, Department of Gastroenterology, Combined Military Hospital, Kharian Pakistan Received: 08 Jul 2020; revision received: 15 Oct 2020; accepted: 21 Oct 2020 poor survival. ${ }^{6}$

An impaired immunity associated with chronic liver disease and increase in the permeability of the intestinal wall leads to translocation of bacteria and subsequent development of SBP. ${ }^{8}$ Bacteria most commonly isolated from ascetic fluid in patients with SBP are usually those of the normal intestinal flora. 7,8 More than $92 \%$ of all cases are monomicrobial with aerobic gram negative bacilli being responsible for more than two thirds of cases. Commonly isolated organisms from ascitic fluid with SBP were Escherichia coli (70\%), Klebsiella species, (15\%), enterococcus facecalis (10\% each), pseudomonas species (4\%) and others (6\%).4,9 Symptoms and signs of SBP are variable. Patients may be asymptomatic, particularly outpatients.

The common symptoms of patients with SBP are fever, pain abdominal, features of hepatic encephalopathy, vomiting diarrhea and GI bleed. ${ }^{8-10}$ Timely diagnosis and early management of SBP by prescribing appropriate antibiotics are measures that can reduce any adverse outcome in these patients. ${ }^{7-10}$ Identification of predisposing risk factors of SBP is of great 
importance because of the significant risk of adverse outcomes related to SBP. Aim of study was to determine the prevalence of SBP in liver cirrhosis with ascites and its association with various clinical parameters in hospitalized group of patients. This will help in identification of high risk groups who need early and appropriate in-hospital care to reduce morbidity and mortality.

\section{METHODOLOGY}

Hospital-based study was carried out in the Department of Medicine Combined Military Hospital (CMH) Kharian Cantt, from July 2019 to April 2020. The study was approved by the Ethical and Research Committee of the hospital (IERB \# Med/04/2019).

Inclusion Criteria: Patients of liver cirrhosis, age 18 years or above, with symptomatic ascites were selected through OPD (Out Patient department) and ER (Emergency Reception) and were hospitalized.

Exclusion Criteria: Patients who were asymptomatic, who were on prophylaxis or who had taken antibiotics during last 3 days preceding induction and those who refused informed consent.

Liver cirrhosis was diagnosed on the basis of relevant history, previous patient's medical record, clinical and laboratory parameters, and abdominal ultrasound findings consistent with liver cirrhosis. The written informed consent was taken. The main symptoms, focused at the time of admission, were fever $(>99 \mathrm{~F})$ with or without chills, recent upper GI bleed (hematemesis, melena) during last 3 days, abdominal pain with or without altered gastrointestinal motility and hepatic encephalopathy (grade 1-4). Causes of cirrhosis, in majority of patients, were chronic viral hepatitis secondary to hepatitis $C$ and $B$ viral infections along with chronic autoimmune and metabolic liver disease in a few cases. Severity of ascites was classified into mild (detectable only on ultrasound), moderate (clinical detectable abdominal distension with positive shifting dullness) and severe (marked abdominal distension with positive fluid thrill). Detailed relevant history and thorough clinical examination of all patients was carried out. For hematological and biochemical investigations $10 \mathrm{mls}$ of venous blood sample was used.

Abdominal paracentesis was carried out using an at the right or left iliac fossa, $>3-4 \mathrm{~cm}$ and $3 \mathrm{~cm}$ medial to the anterior superior iliac spine using aseptic techniques. About $30 \mathrm{mls}$ of ascetic fluid was tapped in a sterile syringe. About $10 \mathrm{mls}$ ascetic fluid was used for cell count and differentials and ascetic fluid total protein estimation. The rest $20 \mathrm{ml}$ ascetic fluid was used for blood culture bottle at bedside.

An abdominal ultrasound was performed in all patients. CT scan brain, CSF analysis of patients with altered sensorium was performed to rule out intracranial pathology. Upper GI endoscopy was performed of patients with recent GI bleed during last 3 day to confirm the variceal cause of GI bleed. Severity of disease was assessed by calculating the Model for end Stage Liver Disease Sodium (MELD-Na+) sore and ChildPugh-Turcotte (CTP) class. MELD score was calculated by using laboratory parameters such as serum bilirubin, creatinine, INR and serum sodium whereas CTP class was calculated as A, B and C by using MD Calculator on the internet.

$20 \mathrm{mls}$ ascetic fluid was used for blood culture at the bed side using and $10 \mathrm{mls}$ of ascitic fluid was sent to lab in a sterile bottle for routine examination including total cells count, differentials and total ascitic fluid protein estimation. Both blood agar and MacConkey agar was used for ascitic fluid culture under supervision of qualified laboratory staff. Results were available after 48 hours.

The SBP was diagnosed on basis of the standard criteria of ascitic fluid absolute ascitic fluid neutrophilic count $>250 / \mathrm{mm}^{3}$ or total ascitic fluid leukocytes count $>500 / \mathrm{cmm}$ (also called neutrocytic ascites) in the absence of any other intra-abdominal surgical source of infection. Patients with absolute ascitic fluid neutrophils count $>250 / \mathrm{mm}^{3}$ and culture positive were labeled as culture positive neutrocytic ascites (CPNA) whereas, patients with absolute ascitic fluid neutrophilic count $>250 / \mathrm{mm}^{3}$ and negative culture were labeled negative neutrocytic ascites (CNNA). Those with positive fluid culture and absolute neutrophilic count $<250$ $/ \mathrm{mm}^{3}$ were classified as Bacterascites.

Blood sample was subjected for various hematological, biochemical parameters including estimation of liver functions, renal functions, blood complete picture, serum electrolytes and coagulation profiles.

The data was compiled and subjected to analysis using SPSS-23 on computer. For categorical variables, frequency or percentages were calculated. To determine the association between SBP and categorical variables chi-square $x 2$ test was used. For continuous variables mean \pm SD was calculated. Whereas, for independent variables student's t-test was used to determine any significant difference between various clinical parameters in SBP. The $p$-value $\leq 0.05$ was considered statistically significant. 


\section{RESULTS}

One hundred twenty-two patients of liver cirrhosis with symptomatic ascites were recruited in the study. The mean age of patients was $56.5 \pm 20$ years. Fifty-five (46.8\%) were males and $67(52.2 \%)$ were females, The cause of cirrhosis was Chronic Hepatitis C in $92 \%$ (113/122), Chronic Hepatitis B in 3.27\% (4/122). The remaining have autoimmune hepatitis in $1.63 \%$ (2/122) and cryptogenic cirrhosis in 2.45\% (3/122).

SBP was diagnosed in $46(37.70 \%)$ patents and the rest $76(62.30 \%)$ were negative for SBP (Figure). Of the

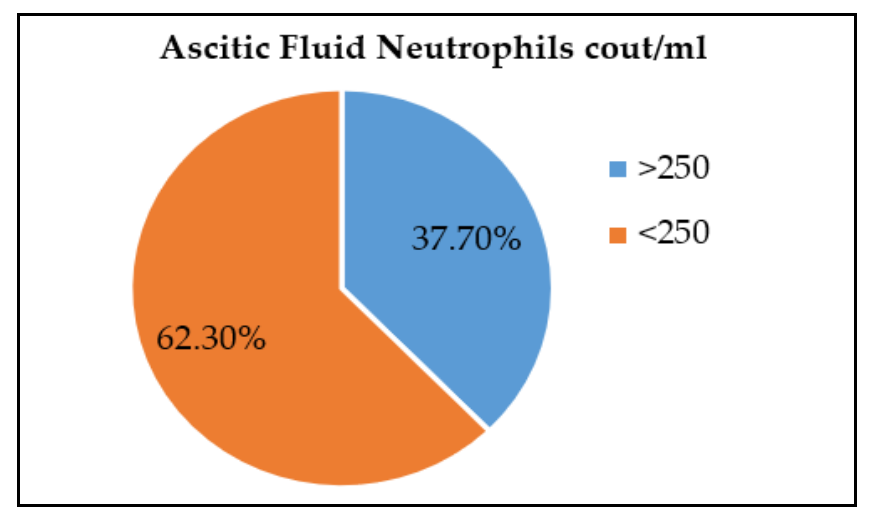

Figure: Frequency of spontaneous bacterial peritonitis.

46 patient that developed SBP 29 (63.05\%) were culture positive and $17(36.95 \%)$ patients were of culture negative neutrocytic ascites (CNNA). Two patients SBP negative group had monomicrobial non-neutrocytic ascites (MNB).

Out of those 31 culture positive cases 26 (84.61\%, $26 / 31$ ) had monomicrobial infection with gram negative bacilli and the rest $7 / 31$ (15.29\%) had growth of gram positive enterococci. Among Gram negative bacilli $73 \%(19 / 26)$ was E.coli and 28\% (7/26) was Klebsiella spp. Similarly among Gram positive enterococci 7 (57\%) yielded growth of streptococcus fecalis spp and the rast 33\% (3/7) were Staphylococcus epidermidis.

Of the 46 , SBP positive patients, $13(26.08 \%)$ had fever, $8(17.56 \%)$ had pain abdomen and 4 patients (8.69\%) presented with upper GI bleed. The rest, 21 patients $(45.65 \%)$ had various grades of hepatic encephalopathy (Table-I). These symptoms were more pronounced in patients with SBP as compared to patients without SBP which was statistically significant $(p<0.05)$. Patients who were SBP positive had severe disease and severe grades of ascites as compared to patient who were SBP negative and this difference was statistically significant (Table-II).

There was no significant difference of gender between SBP positive and SBP negative groups. Of 41 patients with SBP positive $34(83.3 \%)$ were in child's class $C$ and the remaining $7(16.7 \%)$ were in child's class $B$, whereas amongst 90 patients, who were in SBP negative group, 67 (74.4\%) were in Child's class $C$, and $23(25.6 \%)$ were in class B, which was not statistically significant.

The clinical predictor of SBP identified in this study amongst clinical parameters were presence of symptoms, such as hepatic encephalopathy, pain abdomen, and amongst laboratory parameter were, low ascetic protein, high INR, renal dysfunction, high serum

Table-I: Association of clinical symptoms/signs with spontaneous bacterial peritonitis.

\begin{tabular}{l|c|c|c}
$\begin{array}{l}\text { Clinical } \\
\text { Symptoms/ }\end{array}$ Signs & $\begin{array}{c}\text { With } \\
\text { Spontaneous } \\
\text { Bacterial } \\
\text { Peritonitis } \\
\text { (SBP) (n=41) }\end{array}$ & $\begin{array}{c}\text { Without } \\
\text { Spontaneous } \\
\text { Bacterial } \\
\text { Peritonitis } \\
\text { (SBP) (n=81) }\end{array}$ & $\begin{array}{c}\boldsymbol{p} \text { - } \\
\text { value }\end{array}$ \\
\cline { 2 - 3 } & $\mathbf{n ~ ( \% )}$ & $\mathbf{n ~ ( \% )}$ & \\
\hline Fever & $13(28.2)$ & $5(6.1)$ & 003 \\
\hline Pain Abdomen & $6(13.5)$ & $45(55.4)$ & 0.90 \\
\hline $\begin{array}{l}\text { Hepatic } \\
\text { Encephalopathy }\end{array}$ & $21(5.6)$ & $1516.0)$ & 0.05 \\
\hline $\begin{array}{l}\text { Gastrointestinal } \\
\text { Bleed }\end{array}$ & $4(8.6)$ & $19(23.4)$ & 1.39 \\
\hline
\end{tabular}

Table-II: Association of spontaneous bacterial peritonitis with severity of ascites.

\begin{tabular}{l|c|c|c}
\hline $\begin{array}{l}\text { Severity of } \\
\text { Ascites }\end{array}$ & $\begin{array}{c}\text { With } \\
\text { Spontaneous } \\
\text { Bacterial } \\
\text { Peritonitis (SBP) } \\
\mathbf{n ~ ( \% )}\end{array}$ & $\begin{array}{c}\text { Without } \\
\text { Spontaneous } \\
\text { Bacterial } \\
\text { Peritonitis } \\
\text { (SBP), } \mathbf{n}(\%)\end{array}$ & $\begin{array}{c}p \text { - } \\
\text { value }\end{array}$ \\
\hline Mild & $4(6.4 \%)$ & $16(19.8 \%)$ & 0.91 \\
\hline Moderate & $11(23.9 \%)$ & $39(49.3 \%)$ & 0.73 \\
\hline Severe & $31(70.7 \%)$ & $21(30.8 \%)$ & 0.04 \\
\hline
\end{tabular}

Table-III: Lab Parameters with spontaneous bacterial peritonitis and without spontaneous bacterial peritonitis.

\begin{tabular}{l|c|c|c}
\hline \multirow{2}{*}{ Parameters } & $\begin{array}{c}\text { With } \\
\text { Spontaneous } \\
\text { Bacterial } \\
\text { Peritonitis } \\
\text { (SBP) (n=41) }\end{array}$ & $\begin{array}{c}\text { Without } \\
\text { Spontaneous } \\
\text { Bacterial } \\
\text { Peritonitis } \\
\text { (SBP) (n=81) }\end{array}$ & $\begin{array}{c}p \text { - } \\
\text { value }\end{array}$ \\
\cline { 2 - 3 } & Mean \pm SD & Mean \pm SD & \\
\hline $\begin{array}{l}\text { Ascitic Fluid } \\
\text { Protein (gm/ml) }\end{array}$ & O.85 \pm 0.2 & $1.25 \pm 0.3$ & 0.004 \\
\hline WBC & $7.6 / \pm 3.2$ & $7.8 \pm 4.1$ & 0.78 \\
\hline $\begin{array}{l}\text { Platelets (per } \\
\text { cmm) }\end{array}$ & $90.15 \pm 43.7$ & $99.31 \pm 47.9$ & 0.29 \\
\hline $\begin{array}{l}\text { Serum Albumin } \\
\text { (gm/l) }\end{array}$ & $30.68 \pm 3.7$ & $31.33 \pm 4.1$ & 0.39 \\
\hline ALT(u/ml) & $139.05 \pm 69.1$ & $139.04 \pm 72.6$ & 0.99 \\
\hline Bilirubin (umol/dl & $54.36 \pm 17.6$ & $41.03 \pm 20.8$ & 0.002 \\
\hline PT/INR & $2.87 \pm 0.75$ & $2.49 \pm 0.70$ & 0.007 \\
\hline $\begin{array}{l}\text { Creatinine } \\
\text { (umol/ml) }\end{array}$ & $191.5 \pm 72.7$ & $129.2 \pm 52.6$ & 0.001 \\
\hline MELD Score (7-40) & $22 . .1$ & $23.6 \pm 8.3$ & 1.30 \\
\hline
\end{tabular}


bilirubin, severity and severe grades of ascites $(p<0.05)$. There was no statistically significant difference observed in age, serum albumin, MELD score, Child's Pugh scores and Leukocytes count of symptomatic patients with and without SBP (Table-III).

\section{DISCUSSION}

Spontaneous bacterial peritonitis is a severe and often fatal complication of chronic liver disease in patients with ascites. Almost every patient with liver cirrhosis and ascites has the potential to develop SBP during the course of time. On the basis of past studies the estimated prevalence of SBP in cirrhotic patients is between $10-30 \% .11-13$ Although, The estimated prevalence of SBP in our study was marginally high than results of the studies conducted by the researchers from West, ${ }^{6,11,12}$ but comparable to $30-64 \%$ values mentioned in literature from local studies. ${ }^{14,15}$ This difference in prevalence of SBP in local and western studies might be due to the difference in severity of liver disease in population groups subjected to study. This study had relatively more number of patients in child class C than Child class B when compared with literature from the international where most of their studied population was in Child's class B rather than Child's class C. Community based population studies conducted by Sreenvasulu et al, showed even higher incidence of SBP close to $70 \% .15,16$

Most of the patients having SBP presented with clinical symptoms such fever, pain abdomen, vomiting, loose motions or development of features of hepatic encephalopathy as a most predominant manifestations which were itself suggestive of peritoneal infection justify prompt diagnostic paracentesis. ${ }^{16}$ This all supports the findings of our study as the majority of patients in our study had symptoms of fever, and altered sensorium secondary to decompensated chronic liver disease whereas, hepatic encephalopathy and fever was independent predictors of SBP. Variceal hemorrhage predisposes to SBP according to study conducted by Perculeus et al, 17,18 whereas, our findings did not support these observations. This probably due to antibiotic based emergency treatment, received at home or at some primary health care facilities which patients were not mostly aware of, because antibiotic mask the bacteriological findings corresponding SBP.

Figueiredo et al, supports our findings hat low ascitic fluid albumen, upper gastrointestinal bleeding and hepatic encephalopathy are as diagnostic predictors of SBP. ${ }^{19}$ Similar studies conducted by Sheer et al, suggested that patients with decompensated liver cirrhosis who has High MELD score, Child-Pugh class C, high INR, raised serum bilirubin, low platelet count, with altered mental states and abdominal discomforts are more prone to develop SBP. ${ }^{20}$ However, in our study only severe ascites and high INR, low total ascitic protein, high serum bilirubin and creatinine showed strong independent association with SBP. Deranged coagulation profiles and grades of ascites are among the important clinical and laboratory markers used to assess the severity of liver cirrhosis by calculating the Child-Pugh score (CPS). Studied have shown the high CPS predicts the greater risk of SBP in cirrhotic patients. ${ }^{21}$ These finding logically explains that why $70 \%$ patients of liver cirrhosis with SBP are in Child-Pugh class. ${ }^{22}$ According to our study, though the Child-Pugh score was not an independent predictor of SBP but $83.3 \%$ of the patients with SBP were in Child-Pugh grade $\mathrm{C}$.

Chronic HCV infection (92\%) was the major cause of liver cirrhosis in this study. This compared similarly studies from other Asian countries where chronic hepatitis $C$ viral infection is cause of liver cirrhosis in $70-90 \%$ of patients. ${ }^{23}$

The main reason for SBP as reported in literature is bacterial translocation from gut therefore, the commonly isolated pathogens are usually enteric gram negative rods followed by Enterococci e.g. Streptococcus species, ${ }^{24}$ culture positive SBP was observed in $12-20 \%$ in some western literature whereas, its prevalence range from $25-65 \%$ in local studies. ${ }^{24}$ About $80 \%$ of culture positive isolate showed growth of gram negative bacilli with Escherichia coli being the top ranking microorganism associated with SBP followed by Klebsiella and other species. These observations are consistent with the findings of our study and closely match with the findings of other national and international studies conducted by Zaman et al, and Patricia et al respectively. ${ }^{25}$ E.coli $(72 \%)$ was the leading organism isolated during ascitic fluid culture in our study followed by Klebsiella spp $(28 \%)$. These findings are in consistent with the findings projected by other researchers in their studies in which they concluded that E.coli as the dominant pathogen cultured in patients with spontaneous bacterial peritonitis.

\section{ACKNOWLEDGMENT}

We would like to acknowledge department of Chemical Pathology and Microbiology of Combined Military Hospital Kharian, for their assistance during analysis of laboratory parameters and Mr. Irfan for his assistance in data analysis. 


\section{CONCLUSION}

Spontaneous bacterial peritonitis is a frequent and fatal infection among patients with cirrhotic ascites. Clinical symptoms of fever, hepatic encephalopathy, severe ascites, high INR, high serum bilirubin, high serum creatinine high MELD -Na+ and CPS were found well recognizes predictors of SBP. Therefore, all patients with cirrhosis and ascites who are having symptoms such hepatic encephalopathy, fever, severe ascites and high INR should be tested to confirm the SBP. So, a prompt and appropriate treatment may be administered to reduce morbidity and mortality.

\section{Conflict of Interest: None.}

\section{Authors' Contribution}

SFMG: Data concept, design, analysis and discussion, $\mathrm{FH}$ : Data collectiona, discussion, FAS: Discussion, references, SAAG: Discussion, references.

\section{REFERENCES}

1. Maryam K, Samiullah R, SR Khalid. Frequency of Asymptomatic Spontaneous Bacterial Peritonitis in outdoor Patients with Liver Cirrhosis. Pak Armed Force Med J 2015; 58(2): 278-281.

2. Alaniz C, Regal RE. Spontaneous Bacterial Peritonitis: a review of treatment options. PT 2009; 34(4): 204-210.

3. Amoaku D, Kofi NN. Spontaneous bacterial peritonitis among adult patients with ascites attending korle-bu teaching hospital. Pan African Med 2019; 53(1): 37-43.

4. Bendtsen F, Gronbaek H, Hansen JB, Aagaard K, Schhmidt L, Moller SKP, et al. Treatment of ascites and spontaneous bacterial peritonitis-part 1. Dan Med J 2012; 59(1): C4371.

5. Rostkowska KA, Szymanek-Pasternak A. Spontaneous bacterial peritonitis-therapeutic challenges in era of increasing drug resistance of bacteria. Clin Exp Hepatol 2018; 4(4): 224-231.

6. Fernández J, Bauer TM, Navasa M, Rhodes J. Diagnosis, treatment and prevention of spontaneous bacterial peritonitis. Best Pract Res Clin Gastroenterol 2000; 14(6): 975-980.

7. Rimola A, Soto R, Bory F, Arroyo V, Piera C, Rodes J. Reticuloendothelial system phagocytic activity in cirrhosis and its relation to bacterial infections and prognosis. Hepatol 1984; 4(1): 53-58.

8. Llovet JM, Bartoli R, March F, Planas R, Vinado B, Cabre E, et al. Translocated intestinal bacteria cause spontaneous bacterial peritonitis in cirrhotic rats: molecular epidemiologic evidence. J Hepatol. 1998; 28(2): 307-313.

9. Syed VA, Ansari JA, Karki P, Regmi M, Khanal B. Spontaneous bacterial peritonitis (SBP) in cirrhotic ascites: A prospective study in a tertiary care hospital, Nepal. Kathmandu Uni Med J 2007; 5(17): 48-59.
10. Song DS. Spontaneous bacterial peritonitis. Korean J Gastroenterol 2018; 72(2): 56-63.

11. Gunjaca I, Francetic I. Prevalence and clinical outcome of spontaneous bacterial peritonitis in hospitalized patients with liver cirrhosis: a prospective observational study in central part of Croatia. Acta Clin Croat 2010; 49(1): 11-18.

12. Zaman A, Kareem R, Mahmood R, Hameed K, Khan EM. Frequency of microbial spectrum of spontaneous bacterial peritonitis in established cirrhosis liver. J Ayyub Med Coll Abbottabad 2011; 23(4): 15-17.

13. Oladimeji AA, Temi AP, Adekunle AE, Taiwo RH, Ayokunle DS. Prevalence of spontaneous bacterial peritonitis in liver cirrhosis with ascites. Pan Afr Med J 2013; 15(1): 128-132.

14. Nanik R, Habib Q Aftab S, Abdu sattar. Frequency of spontaneous Bacterial Peritonitis with Hepatic Enephalopathy. Medical Chennel 2010; 19(2): 36-38.

15. Sreenivasulu V, Bheemasenachari M. Prevalence of spontaneous Bacterial Peritonitis in cirrhosis of liver with ascites Evol Med Dent Sci 2016; 5(44): 2720-2724.

16. Marciano S, Diaz JM, Dirt Wolf M, Gadano A. spontaneous bacterial peritonitis in patients with cirrhosis: incidence, outcome and management strategies. Hepat Med 2019; 11(2): 13-22.

17. Pericleous M, Sarnoski A, Moor A, Fijten R, Zaman. The clinical management of abdominal ascites, spontaneous bacterial peritonitis, and hepatorenal syndrome. A review of current guide lines and recommendations. Eur J Gastroenterol Hepatol 2016; 28(3); e8-e10.

18. Gabuzenko DV, Arefyev NO. Current approaches to the management of patients with cirrhotic ascites. World J Gastroenterol 2019; 25(28): 3738-3752.

19. Figueiredo FAF, Coelho HSM, Soares JAS. Spontaneous bacterial peritonitis in hepatic cirrhosis: prevalence, predictive, predictive factors and prognosis. Rev Assoc Med Bras 1999; 45(2): 128-136.

20. Shee TA, Runyon BA. Spontaneous Bacterial Peritonitis. Digest Diseas 2005; 23(1): 230-234.

21. Andreu M, Sola R, Sitges-Serra A, Alia C, Gallen M,Vila MC, et al. Risk factors for spontaneous bacterial peritonitis in cirrhotic patients with ascites. Gastroenterol 1993; 104(4): 1133-1138.

22. Cannon MD, Martin P, Carion AF. Bacterial infections in patients with cirrhosis: Don't Get Begged to Death. Dig Dis Sci 2020; 65(1): 31-37.

23. Pugh RN, Murray-Lyon IM. Transection of the esophagus for bleeding esophageal varices. Br J Surg 1973; 60(8): 646-649.

24. Such J, Runyon BA. Spontaneous bacterial peritonitis. Clin Infect Dis 1998; 27(4): 669-74.

25. Patricia LG, Maria da PZG, Carla CM, Ana TM, Carlos SG, Fausto ELP. Etiology of liver cirrhosis in Brazil: chronic alcoholism and hepatitis viruses in liver cirrhosis diagnosed in the state of Espfrito Santo. Clinics 2013; 68(3): 291295. 